\title{
Chemical Compounds Of Granulated Palm Sugar Made From Sap Of Nipa Palm (Nypa Fruticans Wurmb) Growing In Three Different Places
}

\author{
ROSIDAH R. RADAM, Hj. NOOR MIRAD SARI AND Hj. LUSYANI \\ Forestry Faculty of Lambung Mangkurat University, rosidah.radam@yahoo.com
}

\begin{abstract}
Production of granulated sugar from sap of nipa palms in South Kalimantan Province is a new innovation. The purpose of this study was to find out the chemical compounds contained in granulated sugar made from sap of nipa palms growing in 3 different places, which was expected to benefit wider community as a source of alternative sweetener. The chemical compound test of granulated nipa palm sugar was conducted at the Laboratory of Institute for Research and Standardization of Industry, Banjarbaru. Chemical parameters tested were water, sucrose, reducing sugar, fat, protein, phosphorus, and potassium content. The test results showed that the water content of granulated nipa palm sugar in treatment $\mathrm{A}_{1}, \mathrm{~A}_{2}$, and $\mathrm{A}_{3}$ was $3.69 \%, 4.04 \%$, and $2.31 \%$, respectively; the protein content $0.65 \%, 2.19 \%$, and $1.10 \%$; the fat content $0.27 \%, 0.34 \%$, and $0.20 \%$; the reducing sugar content $2.39 \%, 0.51 \%$, and $0.52 \%$; the sucrose content $75.14 \%, 68.15 \%$, and $88.46 \%$; the phosphorus content $1.1342 \%, 1.1196 \%$, and $1.138 \%$; and the potassium content $1.60 \%, 1.40 \%$, and $1.58 \%$, respectively. The test parameters of granulated nipa palm sugar that met the Mandatory Indonesia National Standard (SNI) 01-3743-1995 were the water content of granulated sugar from sap of nipa palms growing in dry place (land), the reducing sugar content and sucrose content in all treatments. It can be concluded from the three required parameters that granulated nipa palm sugar is able to become the source of new sweetener in addition to block arenga palm sugar and crystal cane sugar for the community in South Kalimantan.
\end{abstract}

Keywords: chemical compounds, granulated nipa palm sugar, new sweetener

\section{INTRODUCTION}

Due to the increase in demand for sweeteners, it is necessary to find the way to increase the existing production and to find and utilize alternative sources of sweeteners. It provides the possibility to produce granulated sugar from sap of nipa palms. People tend to demand sweeteners having higher level of sweetness, so that the volume of its use can be reduced (Aloysius Borys Ronicahya, 2013). The production of granulated sugar from nipa sap in South Kalimantan Province is a new breakthrough since people so far process the nipa sap only into liquid and block brown sugar. Granulated nipa palm sugar is favored by many people because in addition to its practicality in shape and use, it also has distinctive aroma and can be stored for a long period of time.

The objectives of this study were to find out the quality of granulated nipa palm sugar and the best place where the palms grew that produced the best sap to be processed into

qualified granulated nipa palm sugar. The results of this study can be used as comparative materials for the use of granulated nipa palm sugar as a source of new sweetener in south Kalimantan Province, in addition to cane sugar and arenga palm sugar.

\section{MATERIALS AND METHODS}

The collecting of nipa sap as raw material for the production of granulated nipa palm sugar was carried out at 3 (three) different places in Rantau Panjang Hilir Village of Tanah Bumbu Regency. The sap that was already tapped was processed into granulated nipa palm sugar. The test of chemical compounds of granulated nipa palm sugar 
was conducted at the Laboratory of Institute for Research and Standardization of Industry, Banjarbaru, South Kalimantan.

The material used in the production of granulated nipa palm sugar was nipa sap tapped from nipa palms in 3 (three) different places.

The equipment used in this study was:

1. Equipment for tapping the sap was knife, bowl, rope, filter and bottle.

2. Equipment for cooking the sap into granulated nipa palm sugar was stove, frying pan, regular stirrer and forkshaped stirrer

3. Equipment for testing chemical compounds of granulated nipa palm sugar was oven, erlenmeyer flask, balance scale, cotton, soxhlet, Kjeldahl flask $100 \mathrm{ml}$, burette, Bucer funnel, filter paper, porcelain cup, exicator, measuring flask and other tools needed in testing.

4. Stationery, camera and other equipment necessary.

Nipa sap samples used in the production of granulated nipa palm sugar in this study were taken from nipa palms in three (3) different places, namely nipa palms growing in river bank (submerged in water), nipa palms growing in the place occasionally submerged in water (influenced by tidal) and nipa palms growing in dry place (land). The nipa sap was then cooked into granulated nipa palm sugar.

The sap tapping was carried out in 3 different places according to treatments. Prior to tapping, palm panicles were shaked for 15-20 days. The palm manicles were cut with angles $30-45^{\circ}$ facing down so as not exposed to direct sunlight. In order to keep the sap lasting long enough, it was given lime of $1.5 \mathrm{~g} / 1$ liter sap, which was dropped in the container of sap to prevent the nipa from damaging while waiting for the production process of granulated nipa palm sugar. The tapping was carried out 2 times a day i.e. in the morning at 07.00 a.m, which was collected at 18.00 p.m, and in the afternoon collected tomorrow at $07.00 \mathrm{am}$.

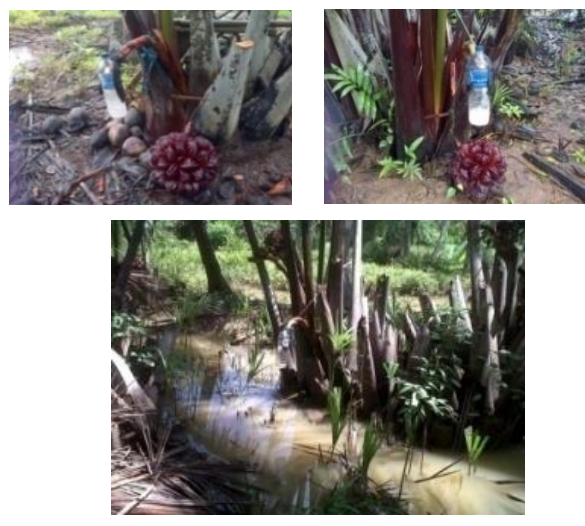

Figure 1. Nipa sap tapped in Rantau Panjang Ilir Village of Tanah Bumbu Regency

\section{Production of Granulated nipa palm sugar}

Granulated nipa palm sugar was produced through several stages, as follows:
a) The sap was filtered and placed in a basin/ container.
b) The clean sap was put into the frying pan and cooked at a heating temperature of $110^{\circ} \mathrm{C}-120^{\circ} \mathrm{C}$, stirred until brown and thickened.
c) To avoid excessive foaming, put coconut oil into the sap with the ratio of 10 grams (1 tablespoon) : 25 liters.
d) The heating was considered complete if the sap droplets which were put into water condensed or looked like sugar fibers.
e) The sap that was still in frying pan was cooled while stirred slowly for about 10 minutes, and set aside for some time to let it expand.
f) The stirring was then repeated rapidly using wooden fork to obtain sugar granules.
g) To get the sugar in the same size, the granules were screened.
h) Then it was packed in plastic bags 
ISSN 2354-5844

Journal of

Wetlands Environmental Management

Volume 2, Number 1, April 2014

110

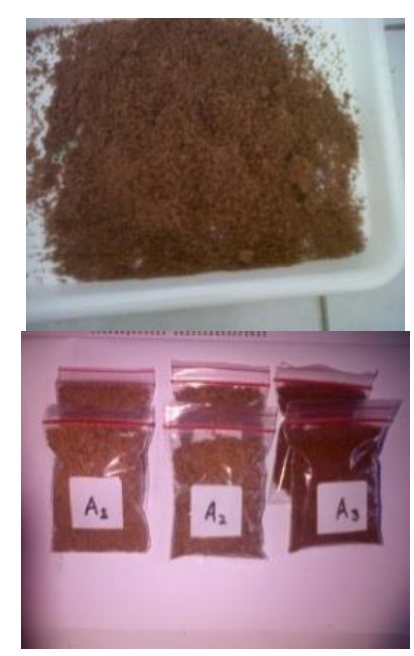

Figure 2. Granulated nipa palm sugar from nipa sap ready to be tested for chemical compounds

\section{Testing for Chemical Compounds of Granulated nipa palm sugar}

The testing for Chemical Compounds of Granulated nipa palm sugar was conducted at the Laboratory of Institute for Research and Standardization of Industry (Baristand), Banjarbaru, South Kalimantan. The parameters of chemical compounds of granulated nipa palm sugar tested were water, sucrose, reducing sugar, fat, protein, phosphorus, and potassium content.

The data of the test results were tabulated and concluded descriptively. The more details can be seen in Table 1 .

Table 1. Tabulation Data Draft of Analysis of Chemical Compounds of Granulated Nipa Palm Sugar from Nipa palms Growing in Three

Different Places

\begin{tabular}{|c|c|c|c|c|c|c|c|}
\hline Place where & & & & & & & \\
\hline $\begin{array}{l}\text { nipa sap } \\
\text { samples were } \\
\text { collected }\end{array}$ & $\begin{array}{l}\text { W } \\
\text { C }\end{array}$ & $\mathbf{S}$ & RS & $\mathbf{F}_{1}$ & & $\mathbf{F}$ & Ph \\
\hline River bank & - & - & - & - & - & - & - \\
\hline $\begin{array}{l}\text { Occasionally } \\
\text { submerged in } \\
\text { water }\end{array}$ & - & - & - & - & - & - & - \\
\hline
\end{tabular}

Note: $\mathrm{WC}=$ Water Content, $\mathrm{S}=$ Sucrose, $\mathrm{RS}=$ Reducing Sugar

Phosphor

$\mathrm{F}=$ Fat, $\mathrm{Pt}=$ Protein, $\mathrm{P}=$ Potassium, $\mathrm{P}=$

The results was compared with SNI 01-37431995 standard (granulated palm sugar), and with the chemical compositions of arenga palm sugar (block) and cane sugar (crystal).

RESULTS

The test results of chemical compounds of granulated sugar from nipa sap tapped in 3 different places, can be seen in Table 2 below:

Dry place

Table 2. Test Results of Chemical Compounds of Granulated Sugar from Nipa Sap in 3 different places

\begin{tabular}{llllll}
\hline \multirow{2}{*}{ No } & \multirow{2}{*}{ Test Parameter } & \multirow{2}{*}{ Unit } & \multicolumn{2}{l}{ Test Result } & \\
\cline { 3 - 6 } & & & $\mathbf{A 1}$ & $\mathbf{A 2}$ & $\mathbf{A 3}_{\mathbf{3}}$ \\
\hline 1 & Water Content & $\mathbf{\%}$ & 3.69 & 4.04 & 2.31 \\
\hline 2 & Protein & $\mathbf{\%}$ & 6.75 & 2.19 & 1.10 \\
\hline 3 & Fat & $\mathbf{\%}$ & 0.27 & 0.34 & 0.20 \\
\hline 4 & Reducing Sugar & $\mathbf{\%}$ & 22.99 & 24.48 & 24.98 \\
\hline 5 & Sucrose & $\mathbf{\%}$ & 0.77 & 1.21 & 1.22 \\
\hline 6 & Phosphor & $\%$ & 1.1342 & 1.1196 & 1.1387 \\
\hline 7 & Potassium & $\%$ & 1.60 & 1.40 & 1.58 \\
\hline
\end{tabular}

Source: Test Results from Institute for Research and Standardization of Industry, Banjarbaru, 2013. 
From the table above, it is known that the granulated nipa palm sugar from nipa palms growing in the place submerged in water $\left(\mathrm{A}_{1}\right)$ had water, protein, fat, reducing sugar, sucrose, phosphorus, and potassium content of $3.69 \%, 0.65 \%, 0.27 \%, 2.39 \%, 75.14 \%$, $1.1342 \%$ and $1.60 \%$, respectively, while in the place occasionally submerged in water $\left(\mathrm{A}_{2}\right) 4.04 \%, 2.19 \%, 0.34 \%, 0.51 \%$, $68.15 \%, 1.1196 \%$ and $1.40 \%$, respectively,

Table 3. Test Results of Chemical Compounds of Granulated Nipa Palm Sugar, SNI 01-3743-1995 Standard (granulated palm sugar), arenga palm sugar (granulated and block) and sugar cane (crystal)

\begin{tabular}{|c|c|c|c|c|c|c|c|}
\hline \multirow[b]{2}{*}{$\begin{array}{l}\text { Test Parameter } \\
(\%)\end{array}$} & \multicolumn{3}{|c|}{ Granulated nipa palm sugar } & \multirow{2}{*}{$\begin{array}{l}\text { SNI 01- } \\
3743- \\
1995 \\
\text { (Granulat } \\
\text { ed) }\end{array}$} & \multirow{2}{*}{\multicolumn{2}{|c|}{$\begin{array}{l}\text { Arenga sugar } \\
\text { granulated block }\end{array}$}} & \multirow[b]{2}{*}{$\begin{array}{l}\text { Cane } \\
\text { Sugar } \\
\text { (crystal) }\end{array}$} \\
\hline & $\mathrm{A}_{1}$ & $\mathrm{~A}_{2}$ & $\mathrm{~A}_{3}$ & & & & \\
\hline$\overline{\text { Nater Content }}$ & 3.69 & 4.04 & 2.31 & Max 3 & 3.78 & 9.26 & 10.32 \\
\hline Protein & 0.65 & 2.19 & 1.10 & - & 2.82 & 2.28 & 0.06 \\
\hline at & 0.27 & 0.34 & 0.20 & - & 0.18 & 0.11 & 0.15 \\
\hline Reducing Sugar & 2.39 & 0.51 & 1.52 & $\operatorname{Max} 6$ & - & 0.53 & 3.7 \\
\hline jucrose & 75.14 & 68.15 & 88.46 & Max 90 & - & 84.31 & 71.89 \\
\hline 'hosphor & 1.1342 & 1.1196 & 1.1387 & - & - & 1.37 & 1.4 \\
\hline otassium & 1.60 & 1.40 & 1.58 & - & - & 1.35 & 0.06 \\
\hline
\end{tabular}

\section{DISCUSSION}

In accordance with the opinion of Tony (1993) that one of the main parameters of the quality of crystal sugar was water content. The high water content $(>0.1 \%)$ can cause the sugar to lump or allow microbes to thrive in sugar packs. The qualified sugar physically looked dry with strong and uniformed crystals. Factors affecting the water content of the crystal sugar were in the process of drying, packing and storage or handling of sugar.

The water content of granulated nipa palm sugar compared to the water content of granulated arenga palm sugar $(3.8 \%)$ in this study was not much different. However, when compared to the water content of cane sugar $(10.32 \%)$, it was much lower and better in quality because sugar as a good sweetener was sugar having low water and in dry place $\left(\mathrm{A}_{3}\right) 2.31 \%, 1.10 \%, 0.20 \%$, $0.52 \%, 88.46 \%, \quad 1.1387 \%$ and $1.58 \%$, respectively.

To determine the quality of granulated nipa palm sugar, the test results were compared with SNI 01-3743-1995 standard on palm sugar (granule), palm sugar (block) and cane sugar (crystal) sold in public market (Table 3). 


\section{Fat Content}

The results of fat content test of granulated nipa palm sugar in treatment $\mathrm{A}_{1}$, $\mathrm{A}_{2}$, and $\mathrm{A}_{3}$ was $0.27 \%, 0.34 \%$, and $0.20 \%$, respectively. The highest fat content was from granulated nipa palm sugar extracted from nipa palms growing in the place submerged in water $\left(\mathrm{A}_{2}\right)$ and the lowest from nipa palms growing in dry place $\left(\mathrm{A}_{3}\right)$. The SNI 01-3743-1995 standard for palm sugar (granule) did not require fat content as one of the quality standards of palm sugar. However, when compared to the fat content of granulated arenga sugar $(0.18 \%)$ and cane sugar $(0.15 \%)$, the fat content of granulated nipa palm sugar was higher. The fat content in granulated sugar would make it taste more savory.

\section{Reducing Sugar Content}

The test results of the reducing sugar content of granulated nipa palm sugar in treatment $\mathrm{A}_{1}, \mathrm{~A}_{2}$, and $\mathrm{A}_{3}$ was $2.39 \%, 0.51 \%$ and $1.52 \%$, respectively. The highest reducing sugar content was from nipa palms growing in the place submerged in water $\left(\mathrm{A}_{1}\right)$, and the lowest from nipa palms growing in the place slightly submerged in water $\left(\mathrm{A}_{2}\right)$. The SNI 01-3743-1995 standard for palm sugar (granule) required a maximum of $6 \%$ reducing sugar, and all treatments met the requirement. When compared to the reducing sugar content of granulated arenga palm sugar $(0.53 \%)$, the reducing sugar content of granulated nipa palm sugar was slightly higher, but when compared to the reducing sugar content of cane sugar $(5.7 \%)$, it was lower. Therefore, the granulated nipa palm sugar in this study was better than sugar cane. This was in accordance with the opinion of Aloysius Boris Ronycahya (2013) that the good sugar is the sugar containing low reducing sugar content. Reducing sugar consists of glucose (blood sugar) and fructose. The high reducing sugar would slow down the process of granulation and when consumed too much would lead to excess of blood sugar content in the body. Therefore, the granulated nipa palm sugar in this study was safe for consumption because the reducing sugar in it was lower than in sugar cane. In addition to protein, reducing sugar is a sugar component affecting the formation of brown color in the production of granulated nipa palm sugar. The provision of lime into nipa sap was to neutralize the nipa sap that made the granulated nipa palm sugar in this study look dark brown.

\section{Sucrose Content}

The test results of the sucrose content of granulated nipa palm sugar in treatment $\mathrm{A}_{1}$, $\mathrm{A}_{2}$, and $\mathrm{A}_{3}$ was $75.14 \%, 68.15 \%$, and 88.46 $\%$, respectively. The highest sucrose content in granulated nipa palm sugar was from nipa palms growing in dry place $\left(\mathrm{A}_{3}\right)$ and the lowest from nipa palms growing in the place submerged in water $\left(\mathrm{A}_{1}\right)$. The SNI 01-37431995 standard for palm sugar (granule) required the maximum of $90 \%$ sucrose content as the quality standard for palm sugar. All treatments in this study met the quality requirement. When compared to the sucrose content of granulated arenga palm sugar $(84.31 \%)$, the sucrose content of granulated nipa palm sugar was not much different; however, when compared to the sucrose content of cane sugar $(71,89 \%)$, the sucrose content of granulated nipa palm sugar in treatment A1 and A3 was higher. It could be concluded that granulated nipa palm sugar had better quality than cane sugar in terms of sucrose content. It was in accordance with the opinion of Aloysius Boris Ronycahya (2013) that the good sugar is sugar containing high sucrose content because the higher the sucrose content, the higher the capability of sugar to granulize. In addition to glucose and fructose, sucrose will give a sweet taste to granulated nipa palm sugar, so the higher the sucrose content, the sweeter the sugar. Sucrose is a disaccharide formed from monomers in the form of glucose and fructose unit. This compound is known as a source of nutrients formed by plants. Sucrose as a major constituent of sugar is an unstable sugar molecule. The 
heating during the production of granulated nipa palm sugar resulted in the inversion of sucrose and produced a molecule of glucose (dextrose) and fructose (levulose) as reducing sugar.

\section{Phosphor Content}

The test results of the potassium content of granulated nipa palm sugar in treatment $\mathrm{A}_{1}, \mathrm{~A}_{2}$, and $\mathrm{A}_{3}$ was $1.1342 \%, 1.1196 \%$, and $1.1387 \%$, respectively. The highest phosphor content of granulated nipa palm sugar was from sap tapped from nipa palms growing in dry place $\left(\mathrm{A}_{3}\right)$, and the lowest from nipa palms growing in the place slightly submerged in water $\left(\mathrm{A}_{2}\right)$. The SNI 01-37431995 standard for palm sugar (granule) did not require phosphor as one of the quality standards of palm sugar. However, when compared to the phosphor content of granulated arenga palm sugar $(1.37 \%)$, and of cane sugar (1.40\%), the phosphor content of granulated nipa palm sugar was lower.

\section{Potassium Content}

The test results of the potassium content of granulated nipa palm sugar in treatment $\mathrm{A}_{1}, \mathrm{~A}_{2}$, and $\mathrm{A}_{3}$ was $1.60 \%, 1.40 \%$, and $1.58 \%$, respectively. The highest potassium content was found in granulated nipa palm sugar that the sap tapped from nipa palms growing in the place submerged in water $\left(\mathrm{A}_{1}\right)$, and the lowest from nipa palms growing in the place slightly submerged in water $\left(\mathrm{A}_{2}\right)$. The SNI 01-3743-1995 standard for palm sugar (granule) did not require potassium as one of the quality standards of palm sugar. When compared to potassium content of granulated arenga palm sugar $(1.35 \%)$, the potassium content of granulated nipa palm sugar was not much different, but when compared to cane sugar $(0.06 \%)$, the potassium content of granulated nipa palm sugar was higher. (Amanda Cros, 2008), potassium is an important macromineral in granulated nipa palm sugar that can assist in the process of electrolyte solution balancing.

\section{CONCLUSIONS}

1. The chemical compounds of granulated nipa palm sugar made from the sap of nipa palms growing in the place submerged in water $\left(\mathrm{A}_{1}\right)$ had water, protein, fat, reducing sugar, sucrose, phosphorus, and potassium content of $3.69 \%, 0.65 \%$, $0.27 \%, 2.39 \%, 75.14 \%, 1.1342 \%$ and $1.60 \%$, respectively, while in the place occasionally submerged in water $\left(\mathrm{A}_{2}\right)$ $4.04 \%, 2.19 \%, 0.34 \%, 0.51 \%, 68.15 \%$, $1.1196 \%$ and $1.40 \%$, respectively, and in dry place $\left(\mathrm{A}_{3}\right) 2.31 \%, 1.10 \%, 0.20 \%$, $0.52 \%, 88.46 \%, 1.1387 \%$ and $1.58 \%$, respectively.

2. The test parameters that met the SNI 013743-1995 standard for palm sugar in the form of granules was the water content of granulated nipa palm sugar made from nipa sap tapped from nipa palms growing in dry place/land $\left(\mathrm{A}_{3}\right)$, the reducing sugar content $(\max 6)$ and the sucrose content (max 90) of granulated nipa palm sugar from nipa palms growing in all places. Of 3 (three) required parameters, it can be concluded that granulated nipa palm sugar can be used as a source of new substitute sweetener replacing crystal cane sugar and block arenga palm sugar for the community in South Kalimantan.

3. Compared to block arenga palm sugar, the water, protein and phosphorus content of granulated nipa palm sugar was lower. The average fat content was slightly higher, and the reducing sugar content was higher but only in treatment $\mathrm{A}_{2}(0.51$ $\%)$. The reducing sugar content of granulated nipa palm sugar was almost equal to block arenga palm sugar $(0.53$ $\%)$. The sucrose content was lower except in the treatment $A_{3}$, which was slightly higher. The phosphorus content of granulated nipa palm sugar was lower than the phosphorus content of arenga palm sugar. The potassium content of granulated nipa palm sugar was slightly higher than the block arenga palm sugar.

4. Compared to crystal cane sugar, the average water, reducing sugar and 
ISSN 2354-5844

phosphorus content of granulated nipa palm sugar was lower than crystal cane sugar. While the fat, sucrose and potassium content of granulated nipa palm sugar was slightly higher.

5. In terms of the reducing sugar content, granulated nipa palm sugar was safe to be consumed primarily to maintain stable blood sugar in the body.

\section{SUGGESTIONS}

1. The best granulated nipa palm sugar in this study based on 3 parameters required by the SNI 01-3743-1995 standard for granulated palm sugar, namely water, reducing sugar and sucrose content, was the granulated nipa palm sugar in treatment $A_{3}$, that was granulated nipa palm sugar made from the sap tapped from nipa palms growing in dry place (land).

2. At the time of collecting nipa sap either in the afternoon or in the morning, in order to prevent the sap from fermenting, the sugar production should be carried out immediately because if the sap is already fermented, it will inhibit the production of granulated nipa palm sugar. To anticipate this, the sap can be given lime and boiling treatment for a few minutes.

\section{ACKNOWLEDMENTS}

The authors would like to thank to:

The Rector of Lambung Mangkurat University of National Education Ministry, who has provided funding for the implementation of this fundamental study, the Chairman of the Research Center of Lambung Mangkurat University, the Dean of Forestry Faculty, the Chairman of Forestry Department, the Head of the Institute for Research and Standardization of Industry Banjarbaru South Kalimantan, and all those who have supported the conduct of this study.

\section{REFERENCES}

Adi Mustika, 2006. Abundant Blessing of Nipa. http://adimust. wordpress.com/bacatulisan/berkah-nipah-yang-melimpah

Alamendah 2012, Nipa (Nypa Fruticans Jpg) http://alamendah. wordpress.com/2009/12/nipah-nypafruticans.jpg

Anna Poedjiadi, 1994. Fundamentals of Biochemistry. Indonesia University. Publisher. Yogjakarta

Aloysius Boris Ronycahya, 2013. Production of sugar and analysis of sugar quality. Production of block brown sugar, granulated palm sugar, invert sugar and starch hydrolysis products as well as quality analysis of sugar product.

Dahlan, Muhammad H, Sari Dewi Djatmiko, Ismadyar. 2004. Nipa sap concentration using cellulose acetate membranes. Journal of Chemical Engineering vol.5 no 2. Sriwijaya University Department of Chemical Engineering, Palembang. Accessed on 23 october 2013.

Fauzan Azima, 1997. Preparation and Evaluation of Quality of Granulated Palm sugar from Nipa Sap. Journal of Agricultural Technology. Andalas University. $\quad$ http://books. google.com/books/about/laporan-

Penelitian-pembuatan-dan-evaluasi-mutugula-semut-dari-nira-nipah

Kampung desain 2012, Equipment for Granulated Nipa Palm Sugar Production. http://kampungdesain.blogspot.com/2008/ 02/alat-pembuat-gula-semut-60-danbila.html

Rahman A.K. dan Y Sudarto. 1991. Nipa A New Source of Sweeteners. Kanisius. Jogyakarta.

Riyadi, A. 2010. Nipa brings blessing. Journal of energy. http://jurnal energi.com/news/55.nipah-membawaberkah

Tony, Lukman Lutony.1993. Plants That Are Sources of Sweeteners. Penebar Swadaya. Jakarta 
ISSN 2354-5844

Journal of

Volume 1, Number 2, April 2014

Wetlands Environmental Management 